\title{
Water Quality Analysis of River PAMBA using WQI Method and GIS Mapping
}

\author{
Subha Lekshmi ${ }^{1}$, Athira Somarajan ${ }^{2}$, Merlin Daniel ${ }^{3}$, Vishak Sasidhar ${ }^{4}$ \\ ${ }^{1}$ Assistant Professor, \\ ${ }^{234}$ Student \\ Civil Department, \\ Musaliar College of Engineering \& Technology, \\ Pathanamthitta
}

\begin{abstract}
River Pamba is the third longest river in the South Indian state of Kerala. One of the most famous pilgrim centre in South India , Sabarimala dedicated to Lord Ayyappa is located in the banks of Pamba. During pilgrimage season, pilgrims use river water for various sanitary purposes and the water gets contaminated. This paper deals with the water quality analysis of River Pamba in three stages - before, during and after pilgrimage season and assess the water quality using Water Quality Index method and GIS mapping. The parameters analysed are pH, Turbidity, Conductivity, Chloride, Total Alkalinity, Total Acidity, Total Hardness, Total Dissolved Solids, Coliforms and E-coli.
\end{abstract}

Keywords- pH, Turbidity, Conductivity, Chloride, Total alkalinity, Total acidity, Total Hardness, TDS, Coliforms, Ecoli,pilgrim season,GIS mapping, River Pamba, Water Quality Index,

\section{I.INTRODUCTION}

River Pamba is one of the major source of drinking water in Pathanamthitta and Alappuzha District of Kerala. Around thirty lakh people depend on this river and its tributaries for their different needs. The pilgrim season at Sabarimala starts from November to January every year. During this period, the water gets polluted more due to the sanitary activities done by pilgrims. So the water quality analysis should be done to check the extent of pollution.

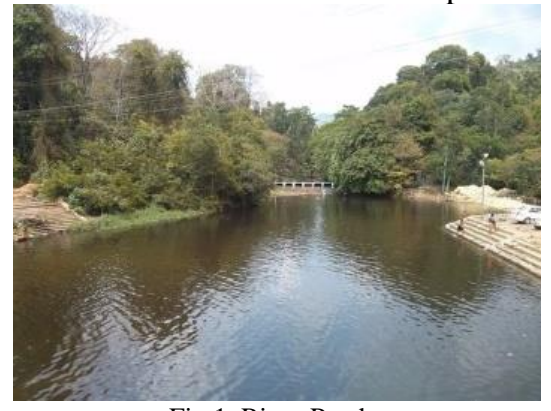

Fig 1. River Pamba

\section{OBJECTIVES}

$>$ To assess the water quality of River Pamba at different wards of Perunad panchayath.

$>$ To analyse the water quality before, during and after pilgrimage season using WQI method and GIS mapping.

$>$ To check whether the water quality is within the standards, and hence suitable or not for domestic and other purposes.

\section{SCOPE}

The water samples were collected and analysed- before , during and after pilgrimage season. Later on the next years, this information will be useful for taking pollution preventive measures before pilgrimage season starts. This method can be extended to the areas where Pamba river flows and affected by the pilgrim season. This methods helps to determine the polluted areas.

\section{METHODOLOGY}

$>$ Samples were collected from 14 wards of Perunad Grama panchayath. The selected wards are $\operatorname{Mukkam}(\mathrm{S} 1), P e r u n a d(S 2)$, Madathummoozhy (S3)

Puthukkada(S4),Arayanjilimon(S5), Thulappally

$>$ (S6), Naranamthodu (S7), Sabarimala(S8), Manakkayam (S9), Kannanumon (S10), Nedumon (S11), Mampara (S12), Kakkad(S13), Madamon (S14).

$>$ The water was tested for $\mathrm{pH}$, Turbidity, Conductivity, Chloride, Total Alkalinity, Total Acidity, Total Hardness, Total Dissolved Solids, Coliforms and E-coli.

TABLE 1 DESIRABLE LIMITS OF PARAMETERS

\begin{tabular}{|c|l|}
\hline Parameters & Remarks \\
\hline $\mathrm{pH}$ & $6.5-8$ \\
\hline Turbidity & $1 \mathrm{NTU}$ \\
\hline Alkalinity & $200 \mathrm{mg} / \mathrm{L}$ \\
\hline Acidity & $150 \mathrm{mg} / \mathrm{L}$ \\
\hline TDS & $500 \mathrm{mg} / \mathrm{L}$ \\
\hline Total Hardness & $200 \mathrm{mg} / \mathrm{L}$ \\
\hline Chloride & $250 \mathrm{mg} / \mathrm{L}$ \\
\hline Coliforms & Zero \\
\hline E-coli & Zero \\
\hline
\end{tabular}

After finding the values of these parameters, Water Quality Index of each point is calculated. The calculation of WQI is done using Weighted Arithmetic Mean Method.

WQI is calculated by the following equation:

$$
\mathrm{WQI}=\sum_{n=1}^{n} q n w n / \sum_{n=1}^{n} w n
$$

- $\quad \mathrm{Wn}=\mathrm{k} / \mathrm{sn}$

$\mathrm{Wn}=$ unit weight for $\mathrm{nth}$ parameter

$\mathrm{Sn}=$ standard permissible value for $\mathrm{nth}$ parameter 
$\mathrm{k}=$ proportionality constant.

- $\mathrm{qn}=100$ (vn-vi) / (vs-vi)

vs $=$ Standard value, vn $=$ observed value, vi = ideal value

In most cases $v i=0$ except in certain parameters like $\mathrm{pH}$

- $\quad \mathrm{q} \mathrm{pH}=100(\mathrm{v} \mathrm{pH}-7.0) /(8.5-1.0)$

\section{TABLE 1 SUITABILITY OF WQI FOR HUMAN CONSUMPTION}

\begin{tabular}{|c|c|}
\hline Range & Remark \\
\hline $0-25$ & Excellent \\
\hline $26-50$ & Good \\
\hline $51-75$ & Bad \\
\hline $76-100$ & Very bad \\
\hline $100 \&$ above & Unfit \\
\hline
\end{tabular}

$>$ GIS Mapping is done using Arc GIS.

\section{RESULTS AND DISCUSSIONS}

\section{A. Test Results}

The test results of water samples collected from different wards of Perunad grama panchayath before pilgrimage season are shown in TABLE 3.

TABLE 3 TEST RESULTS BEFORE PILGRIM SEASON

\begin{tabular}{|c|c|c|c|c|c|c|c|c|c|c|}
\hline 芦 & 涪 & 离 & $\bigcup_{\text {U્વ }}$ & $\tilde{\theta}$ & 焉: & 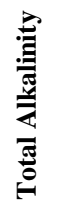 & 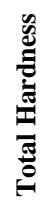 & $\frac{0}{0}$ & 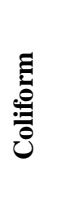 & 豙 \\
\hline S1 & 5.94 & 1.1 & 74 & 34 & 10 & 20 & 20 & 8 & 1100 & 20 \\
\hline S2 & 6.5 & 1.4 & 65 & 21 & 11 & 22 & 16 & 6 & 540 & 17 \\
\hline S3 & 6.06 & 8 & 37 & 20 & 16 & 24 & 16 & 4 & 1100 & 29 \\
\hline S4 & 5.45 & 6.1 & 52 & 36 & 14 & 19 & 22 & 12 & 960 & 24 \\
\hline S5 & 6.1 & 1.7 & 44 & 41 & 10 & 20 & 18 & 10 & 890 & 13 \\
\hline S6 & 6.45 & 2.5 & 40 & 50 & 12 & 22 & 14 & 6 & 1090 & 19 \\
\hline S7 & 5.59 & 6 & 64 & 27 & 11 & 23 & 19 & 12 & 460 & 10 \\
\hline S8 & 5.57 & 1.3 & 55 & 30 & 10 & 20 & 24 & 6 & 400 & 15 \\
\hline S9 & 6.12 & 7.8 & 32 & 51 & 14 & 24 & 15 & 7 & 750 & 21 \\
\hline S10 & 6.3 & 5 & 47 & 43 & 12 & 18 & 20 & 4 & 680 & 18 \\
\hline S11 & 5.81 & 4.1 & 51 & 32 & 14 & 21 & 22 & 10 & 980 & 24 \\
\hline S12 & 5.75 & 1.3 & 74 & 47 & 10 & 18 & 18 & 5 & 460 & 28 \\
\hline S13 & 5.63 & 1.1 & 76 & 28 & 10 & 22 & 26 & 8 & 870 & 16 \\
\hline S14 & 6.21 & 5 & 69 & 31 & 10 & 19 & 24 & 4 & 800 & 15 \\
\hline
\end{tabular}

Remarks

- Low pH in all wards (less than 6.5) except Perunad, which showed a value of 6.5.

- Turbidity is within the desirable limits in all wards, but for drinking purpose, it is not safe (should be less than 1NTU).

- TDS, total hardness, chloride, alkalinity, acidity is within the desirable limit.

- $\quad$ E-coli and Coliforms are present

The test results of water samples collected from different wards of Perunad grama panchayath during pilgrimage season are shown in the TABLE 4

TABLE 4 TEST RESULTS DURING PILGRIM SEASON

\begin{tabular}{|c|c|c|c|c|c|c|c|c|c|c|}
\hline 离 & $\frac{\pi}{2}$ & 总 & ب. & $\stackrel{\mathscr{\theta}}{1}$ & 至 & 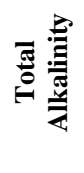 & 营 & 窇 & U: & 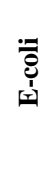 \\
\hline S1 & 7.1 & 6.1 & 80 & 40.4 & 9.3 & 20.5 & 28 & 12 & 1500 & 41 \\
\hline $\mathrm{S} 2$ & 7.6 & 7.2 & 68 & 34 & 10 & 23.1 & 25 & 10 & 950 & 30 \\
\hline S3 & 6.9 & 10.4 & 41 & 29 & 11.5 & 25.4 & 26 & 9.3 & 1320 & 48 \\
\hline S4 & 7.54 & 9.8 & 63 & 45 & 10.3 & 21 & 29 & 14.6 & 1200 & 40 \\
\hline S5 & 7.4 & 7.3 & 49 & 48 & 9.1 & 20.6 & 24 & 13.3 & 1100 & 32 \\
\hline S6 & 7.45 & 8.7 & 51 & 55 & 11.1 & 22.4 & 21 & 8.09 & 1400 & 39 \\
\hline S7 & 6.6 & 9.9 & 68 & 39 & 10.5 & 25.6 & 25 & 15.2 & 960 & 28 \\
\hline S8 & 7.3 & 12.1 & 63 & 41 & 9.6 & 25 & 34 & 12.1 & 1650 & 41 \\
\hline S9 & 7.9 & 11.3 & 45 & 60 & 13 & 26 & 20 & 19.2 & 900 & 42 \\
\hline $\begin{array}{l}\mathrm{S} 10 \\
\end{array}$ & 7.74 & 8.2 & 50 & 49 & 11.5 & 19.4 & 21 & 10 & 1250 & 40 \\
\hline S11 & 6.9 & 7.7 & 68.6 & 41 & 12.4 & 23 & 26 & 13.2 & 1400 & 42 \\
\hline S12 & 6.89 & 6.1 & \begin{tabular}{|l|}
79 \\
\end{tabular} & 52 & 8.6 & 20.1 & 20 & 14.2 & 1080 & 44 \\
\hline S13 & 7.09 & 5.4 & 81 & 32 & 9.2 & 24 & 30 & 13.6 & 1350 & 36 \\
\hline S14 & 7.81 & 9.5 & 72 & 44 & 9.4 & 20 & 29 & 9.4 & 1150 & 29 \\
\hline
\end{tabular}




\section{Remarks}

- $\quad \mathrm{pH}$, TDS, Total acidity, Total alkalinity, Total hardness, Chloride is within the limit.

- The value of turibidity is high compared to the values in before pilgrimage season.

- E-coli and coliform are present and have greater value compared to before pilgrimage season.

The test results of water samples collected from different wards of Perunad grama panchayath after pilgrimage season are shown in the table 5.

TABLE 5 TEST RESULTS AFTER PILGRIM SEASON

\begin{tabular}{|c|c|c|c|c|c|c|c|c|c|c|}
\hline 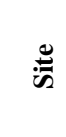 & $\overline{2}$ & $\stackrel{:}{:}$ & ن & $\tilde{\theta}$ & 丽递 & 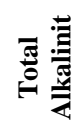 & 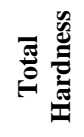 & 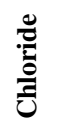 & 己 & 豙 \\
\hline S1 & 7 & 6 & 82 & 41 & 9.5 & 21 & 26 & 11.5 & 1520 & 50 \\
\hline S2 & 7.3 & 6.8 & 69 & 36 & 10.6 & 25 & 23 & 9 & 990 & 35 \\
\hline S3 & 6.7 & 9.6 & 43 & 31 & 12 & 26 & 25 & 9.1 & 1400 & 50 \\
\hline S4 & 7.4 & 8.9 & 64 & 47 & 10.5 & 21.5 & 25 & 13.2 & 1290 & 45 \\
\hline S5 & $\begin{array}{l}7.1 \\
\end{array}$ & 7.1 & 51 & 61 & 9.6 & 21 & 21 & 12 & 1200 & 38 \\
\hline S6 & 7.2 & 8.4 & 52 & 57 & 11.9 & 23.6 & 20 & 7 & 1490 & 42 \\
\hline S7 & 6.3 & 9 & 70 & 43 & 10.8 & 25.9 & 22 & 14 & 1010 & 31 \\
\hline S8 & 7.25 & 11.9 & 65 & 46 & $\begin{array}{ll}10.1 \\
\end{array}$ & 26 & 29 & 12 & 1800 & 49 \\
\hline S9 & 7.5 & 10.6 & 46 & 61 & 13.5 & 27 & 19 & 18.9 & 990 & 48 \\
\hline S10 & 7.6 & $\begin{array}{l}7.8 \\
\end{array}$ & 54 & 50 & 12 & 20.5 & 19 & 9.5 & 1300 & 43 \\
\hline S11 & 6.6 & 7.3 & 69 & 42 & 13.1 & 24.2 & 24 & 13 & 1450 & 44 \\
\hline S12 & 6.8 & 6 & 81 & 55 & 8.9 & 21.1 & 18 & $\begin{array}{l}13.9 \\
\end{array}$ & 1100 & 49 \\
\hline S13 & 7 & 5.1 & 82 & 34 & 9.8 & 25.4 & 26 & 13.3 & 1400 & 40 \\
\hline S14 & 7.6 & 9 & 73 & 45 & 9.9 & 21.3 & 24 & 9 & 1250 & 35 \\
\hline
\end{tabular}

Remarks:

- $\quad \mathrm{Ph}$, Total acidity, Total alkalinity, EC, TDS, Chloride is within the limit.

- Turbidity is above the limit and there is a slight decrease in the value compared to during pilgrimage season.

- E-coli and coliform content increased.

B. Water Quality Index

\section{$>$ Calculation of $\mathrm{Wn}$}

TABLE 6 CALCULATED VALUES OF Wn

\begin{tabular}{|c|c|c|c|c|}
\hline Sl.no & Parameter & Sn & $\mathbf{1 / S n}$ & Wn=k/Sn \\
\hline 1 & $\mathrm{pH}$ & 8.5 & 0.117 & 0.216 \\
\hline 2 & Turbidity & 5 & 0.2 & 0.368 \\
\hline 3 & EC & 400 & 0.0025 & 0.004 \\
\hline 4 & TDS & 500 & 0.002 & 0.0036 \\
\hline 5 & Total Acidity & 150 & 0.00667 & 0.0122 \\
\hline 6 & Total Alkalinity & 200 & 0.005 & 0.00921 \\
\hline 7 & Total Hardness & 200 & 0.005 & 0.00921 \\
\hline 8 & Chloride & 250 & 0.004 & 0.007368 \\
\hline 9 & Coliform & 10 & 0.1 & 0.1842 \\
\hline 10 & E-coli & 10 & 0.1 & 0.1842 \\
\hline & TOTAL & & $\mathbf{0 . 5 4 2}$ & $\mathbf{1}$ \\
\hline
\end{tabular}

The value of $k=1 / \sum\left(\frac{1}{S i}\right)=1.845$ 


\begin{tabular}{|c|c|c|c|c|}
\hline \multirow[b]{2}{*}{ Sl.no } & \multirow[b]{2}{*}{ Station } & \multicolumn{3}{|c|}{ WQI } \\
\hline & & $\begin{array}{c}\text { Before } \\
\text { pilgrim }\end{array}$ & During pilgrim & $\begin{array}{r}\text { After } \\
\text { pilgrim }\end{array}$ \\
\hline 1 & Mukkam & 2086.78 & 2885.291 & 2936.499 \\
\hline 2 & Perunad & 1043.76 & 1867.21 & 1942.766 \\
\hline 3 & Madathumoozhy & 2152.39 & 2598.24 & 2746.218 \\
\hline 4 & Puthukkada & 1880.13 & 2364.43 & 2530.718 \\
\hline 5 & Arayanjilimon & 1689.14 & 2145.02 & 2334.37 \\
\hline 6 & Thulapally & 2069.44 & 2721.54 & 2886.988 \\
\hline 7 & Naranamthodu & 930.59 & 1898.96 & 1994.177 \\
\hline 8 & Sabarimala & 794.97 & 3208.66 & 3497.35 \\
\hline 9 & Manakkad & 1490.63 & 1831.748 & 1997.596 \\
\hline 10 & Kannanumon & 1332.94 & 2447.57 & 2540.015 \\
\hline 11 & Nedumon & 1897.08 & 2714.73 & 2811.755 \\
\hline 12 & Mampara & 926.82 & 2117.27 & 2163.82 \\
\hline 13 & Kakkad & 1660.24 & 2594.20 & 2690.346 \\
\hline 14 & Madamon & 1549.76 & 2253.729 & 2442.15 \\
\hline & Average WQI & 1689.81 & 2403.49 & 2536.76 \\
\hline
\end{tabular}

Since the Water Quality Index of Pamba river was in the range of 1000 - 3000 which is above 100 in all the 3 seasons(before during and after pilgrim season), the water is unfit for human consumption. High value of WQI may be due to the large amount of coliform present in the river water.
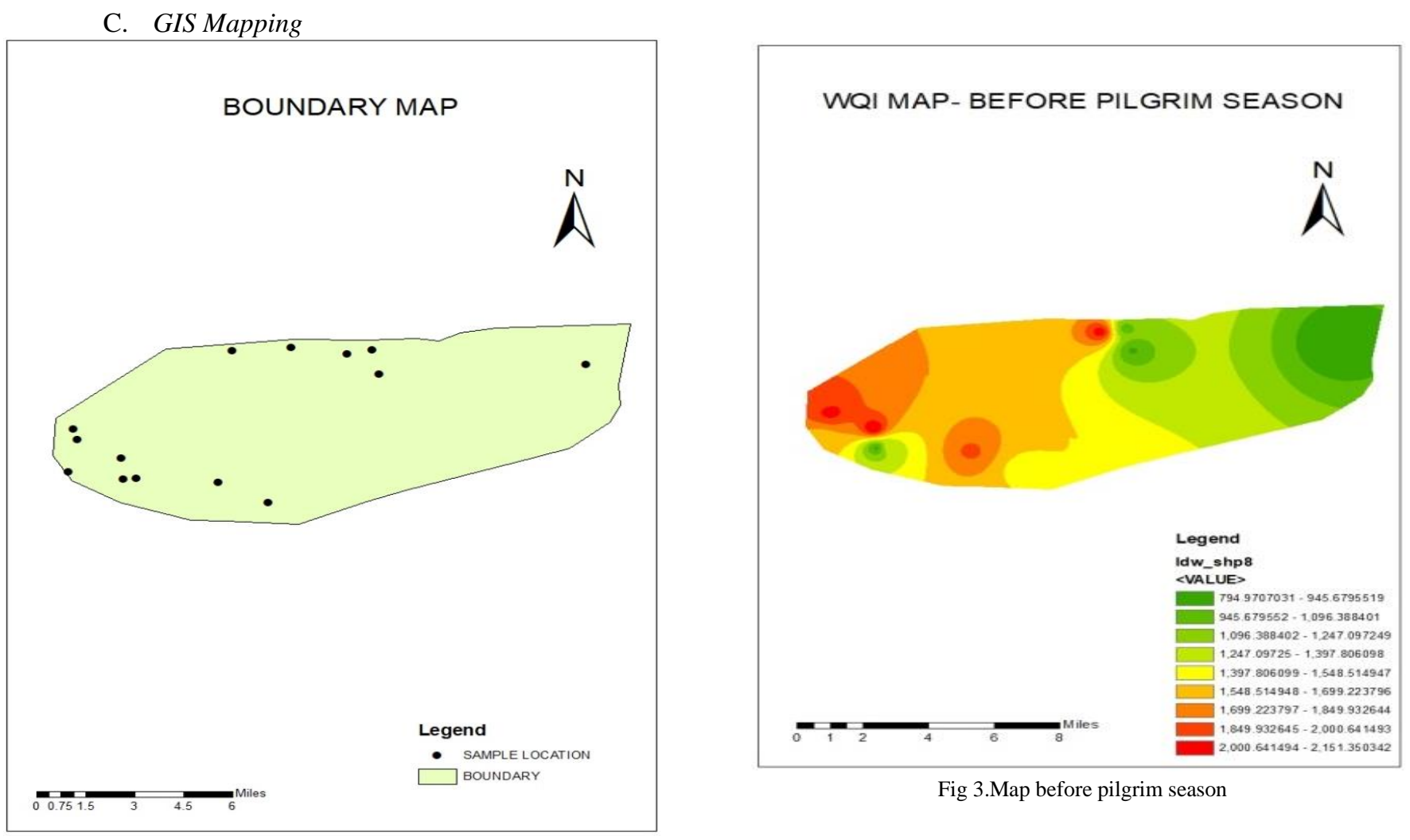

Fig 3.Map before pilgrim season

Fig. 2. Boundary map 


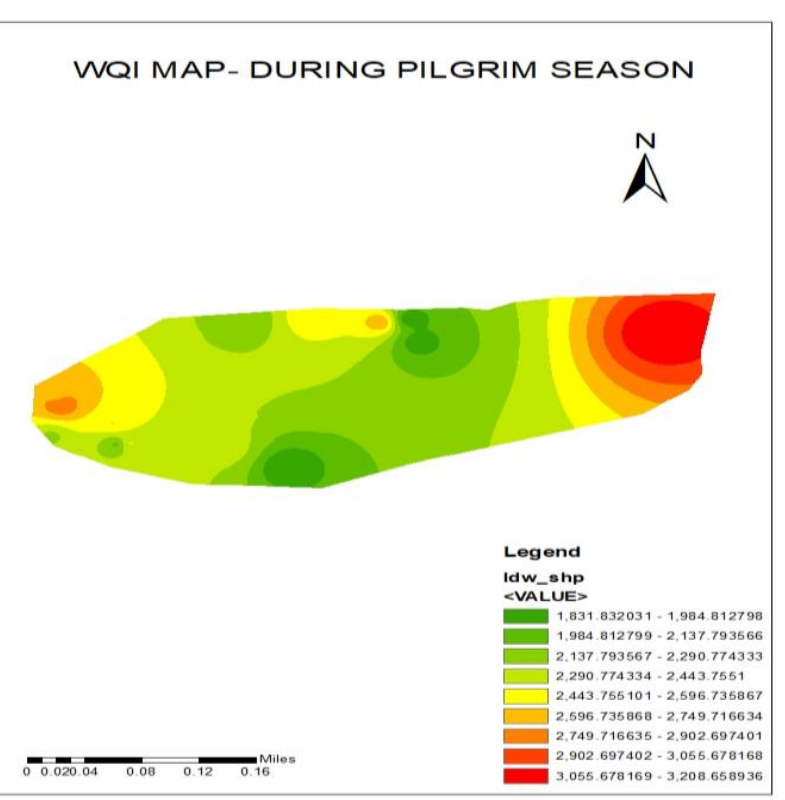

Fig 4.Map during pilgrim season

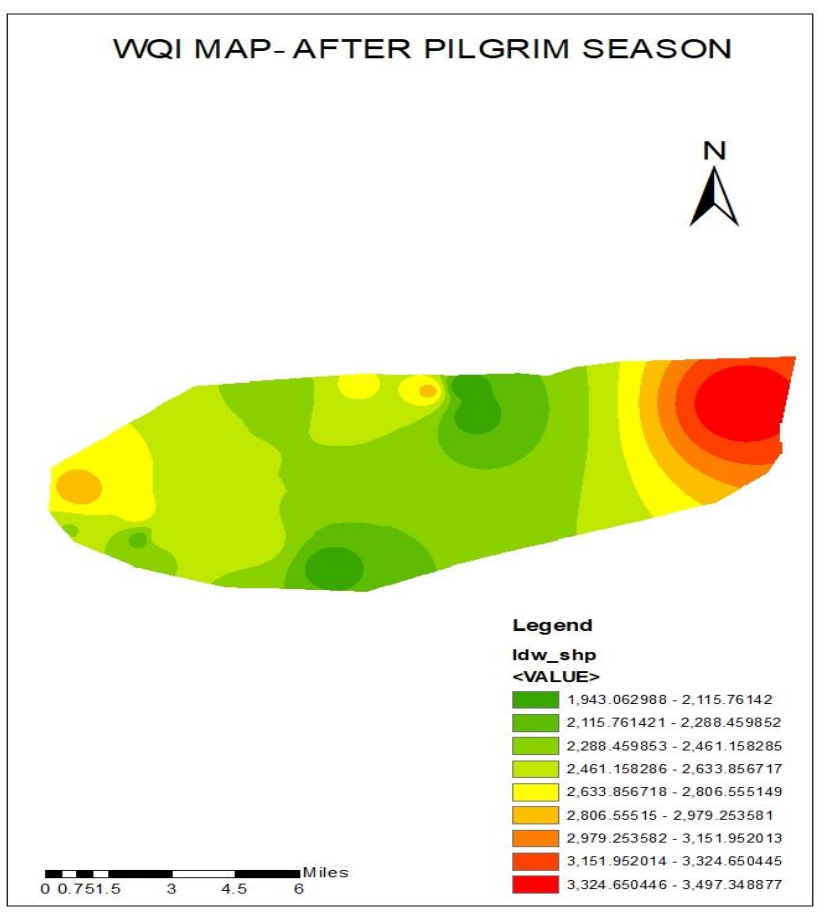

Fig 5. Map after pilgrim season

The GIS map is obtained using IDW Interpolation method. The map is plotted with $\mathrm{X}$ axis as longitude, $\mathrm{Y}$ axis as latitude and $\mathrm{Z}$ axis as WQI. In fig 3,4 and 5, the shades of different colours shows intensity of WQI within the selected boundary. The green colour shows areas with comparatively less WQI and red colour shows areas with high WQI.

\section{CONCLUSION}

In Pamba River, all physic-chemical and biological parameters were fluctuated in the three seasons and in different stations. Raised values of certain parameters like turbidity, total coliform, e-coli clearly indicated pollution of Pamba River. From the test results, it is clear that certain parameters crossed the permissible limit. The high amount of coliform count may be due to the human excreta during pilgrim season. Low discharge of river water during and after pilgrim season is also a factor the increased amount of coliforms. The increased turbidity observed during pilgrim season may be due to the input of organic matter and sewage effluents into the river. The high value of WQI in all places is due to the high value of coliform content.

Remedies to reduce the level of pollution:

- Proper collection and mangament system for different types of waste generated during pilgrim season.

- Proper latrine facilities should be provided at places where pilgrims used to take rest, bathing etc.

- Also, a certain level of water should be maintained by releasing water from storage dams.

- Turbidity can be reduced by stopping the usage of soaps while pilgrims take bath in the river water.

- Powdered roots and shoots of Vetiveria Zizanioides (phytoremediation using plants) can be used for removing bacterias and pollutants.

\section{REFERENCES}

[1] Asit Kumar Behra; Aliva Patnaik; Smita Rout;, "Water Quality Analysis of River Mahanadi in Sambalpur city", International Journal of Scientific and Research Publications, Volume 6, Issue 2 ISSN2250-3153, 2016.

[2] Devendra Dohare; Shriram Deshpande and Atul Kotiya , "Analysis of Ground Water Quality Parameters: A Review", Research Journal of Engineering Science ISSN 2278 - 9472 Vol. 3(5), 26-31, 2014

[3] Kirti Avishek; Kishloy Ranjan;, "Water quality assessment of Harmu river, Ranchi (INDIA)", Suresh Gyan Vihar University Journal of Climate Change and Water, Vol. 4, 2017 pp. 22-27 ISSN: 2347-7741,2017.

[4] Maya M Nair; N Girija; S.Lakshmi; Soumya S. Pillai, "Phytoremediation Potential of Vetiver Zizanioides:A Green Technology to Remove Pollutants from Pamba River by Hydroponic Technique", Indian Journal of Advances in Chemical Science 4(4)464-468, 2016.

[5] Muhammad Mohsin; Samira Safdar; Faryal Asghar; Farrukk Jamal, “Assessment of Drinking Water Quality and its Impact on Residents Health in Bahawalpur City", International Journal of Humanities and Social Science Vol. 3 No. 15, 2015.

[6] Naveen Kumar Arora; Sakshi Tewari and Sachin Singh, "Analysis of water quality parameters of River Ganga during Maha Kumbha, Haridwar", Journal of Environmental Biology ISSN: 0254- 8704, 2013.

[7] S.Punitha and Dr.G.Selvarajan,“ Potable Water Quality Evaluation of Kilvelur Taluk, Nagapattinam District, TamilNadu, India", International Journal for Research in Engineering Application \& Management ISSN : 2454-9150 Vol-04, Issue-06, 2018.

[8] Soumya singha; Dr. C. P. Devadha; Sudhakar Singha; Prof. M. K. Verma, "Assessing Ground Water Quality Using GIS", International Journal of Engineering Research \& Technology, ISSN: 2278-0181, Vol.4 Issue 11, 2015.

[9] T M Vinay, "Water Quality Analysis of River Tungabhadra Near Harihar" IJARIIE-ISSN(O)-2395-4396 Vol-3 Issue-2, 2017. 